\title{
Vandetanib in a Child Affected by Neurofibromatosis Type 1 and Medullary Thyroid Carcinoma with Both NF1 and Homozygous RET Proto-oncogen Germ-line Mutations
}

\author{
(D) Begümhan Demir Gündoğan1, (1) Fatih Sağcan1, (1) Sevcan Tuğ Bozdoğan2, (1) Yüksel Balc13, (D) Ferah Tuncel Daloğlu4, \\ (D) Elvan Çağlar Çıtak ${ }^{1}$
}

${ }^{1}$ Mersin University Faculty of Medicine, Department of Pediatric Oncology, Mersin, Turkey

${ }^{2}$ Çukurova University Faculty of Medicine, Department of Medical Genetics, Adana, Turkey

${ }^{3}$ Mersin University Faculty of Medicine, Department of Radiology, Mersin, Turkey

${ }^{4}$ Mersin University Faculty of Medicine, Department of Pathology, Mersin, Turkey

What is already known on this topic?

Medullary thyroid carcinoma or C-cell hyperplasia are usually associated with other endocrine tumors or a patients with multiple endocrine neoplasia type 2 clinical findings. Germline mutations in both NF1 and RET proto-oncogene have been reported only in a patient with thyroid C-cell hyperplasia. Although vandetanib is frequently used in thyroid medullary carcinoma in the adult age group, there is little data regarding its use in the childhood age group.

\section{What this study adds?}

This is the first report the presence of a double germline mutation involving both NF1 and RET genes and treated with vandetanib.

\begin{abstract}
Cases of neurofibromatosis type 1 (NF1)-associated medullary thyroid carcinoma (MTC) or C-cell hyperplasia are rarely associated with other endocrine tumors or cases with a multiple endocrine neoplasia type 2 . In these patients, mutations were detected in the NF1 gene but no mutations were detected in the RET gene. Although vandetanib has been shown to improve progression-free survival in adults with advanced MTC, data in pediatric patients are limited. Herein, we report the use and outcome of vandetanib in a pediatric MTC case in which NF1 gene and RET proto-oncogen mutation were identified together.
\end{abstract}

Keywords: Medullary thyroid carcinoma, vandetanib, RET proto-oncogene, NF1 gene, children

\section{Introduction}

Neurofibromatosis type 1 (NF1) is a common, autosomal dominant, multi-systemic neurocutaneous disorder. An increased frequency of various endocrine pathologies, such as central precocious puberty, short stature, diencephalic syndrome, growth hormone deficiency or growth hormone hypersecretion has been reported in children. In addition, pheochromocytoma, parathyroid carcinoma, parathyroid adenoma, somatostatin producing neuroendocrine tumor, duodenal carcinoid tumor producing somatostatin, thyroid papillary carcinoma with pheochromocytoma have been described in patients with NF1 $(1,2,3)$.

Medullary thyroid carcinoma (MTC) is a neuroendocrine tumour arising from the calcitonin producing parafollicular C-cells of the thyroid. It accounts for approximately 1-2\% of all thyroid cancers. Clinically, 70-80\% of MTCs are sporadic, while $20-30 \%$ are inherited in an autosomal dominant
Address for Correspondence: Elvan Çağlar Çıtak MD, Mersin University Faculty of Medicine, Department of Pediatric Oncology, Mersin, Turkey

E-mail: caglarcitak@yahoo.com ORCID: orcid.org/0000-0003-1451-1373

- Copyright 2021 by Turkish Pediatric Endocrinology and Diabetes Society

The Journal of Clinical Research in Pediatric Endocrinology published by Galenos Publishing House.
Conflict of interest: None declared Received: 24.03 .2020 Accepted: 01.07.2020 
fashion (4). Hereditary MTCs may be part of multiple endocrine neoplasia type 2 (MEN) and occur in three different clinical forms as MEN2A, MEN2B and familial MTC. Mutated "REarrangement during Transfection" (RET) protooncogene plays a very significant role in the development of human neuroendocrine tumors and tumor syndromes. $R E T$ proto-oncogene mutation has been reported in both sporadic and familial cases (4).

Cases of NF1-associated MTC or C-cell hyperplasia are rarely associated with other endocrine tumors or with MEN2 clinical findings. In these patients, mutations were detected in the NF1 gene but no mutations were detected in the RET gene $(5,6,7,8,9,10,11,12)$.

To our knowledge, germline mutations in both NF1 and RET proto-oncogene have been reported only in one patient with thyroid C-cell hyperplasia, but no simultaneous mutation of these two genes in MTC has been reported (12).

In this article, we present a 15-year-old male patient diagnosed with both NF1 and MTC, and also had mutations in both NF1 and RET genes, and will discuss the effectiveness of vandetanib therapy in MTC.

\section{Case Report}

A 15-year-old boy was admitted to a hospital with progressively increasing midline neck swelling for two months. Physical examination revealed a firm and mobile $3 \times 2 \mathrm{~cm}$ swelling on the left side of the neck, multiple lymph nodes, multiple café-au-lait macules, and inguinal and axillary freckling. Lisch nodule was detected in the eye examination. Cranial magnetic resonance imaging showed focal areas of signal intensity and bilateral optic glioma. Family history revealed that his brother and mother had similar findings and also that his mother had a diagnosis of neurofibromas. Cervical ultrasonography and computed tomography showed a heterogeneous mass lesion in the left thyroid lobe and multiple lymphadenopathy. Total blood count and biochemical analysis were within normal range. Thyroid-stimulating hormone, free triiodothyronine and free thyroxine levels were $21.038 \mu \mathrm{IU} / \mathrm{mL}(0.35-5.5 \mu \mathrm{IU} / \mathrm{mL})$, $6.28 \mathrm{pmol} / \mathrm{L}$ (8-22 pmol/L) and $14.76 \mathrm{pmol} / \mathrm{L}$ (0.83-1.43 ng/ $\mathrm{dL})$, respectively. After the cervical nodes were resected, pathological investigation demonstrated metastasis of MTC, and the patient was referred to the department of pediatric surgery. Preoperative calcitonin and carcinoembryonic antigen (CEA) levels were $2000 \mathrm{pg} / \mathrm{mL}$ (0-8.4 pg/mL) and $116.52 \mathrm{ng} / \mathrm{mL}(0-2.5 \mathrm{ng} / \mathrm{mL})$, respectively. The patient was admitted to our department after total thyroidectomy and radical neck dissection. He was investigated for MEN syndrome. Serum parathyroid hormone, serum gastrin, 24- hour urinary catecolamine and metanephrine levels were within normal range.

Histopathologic examination showed MTC with presence of perineural and lymphovascular invasion (Figure 1A-1 F). Due to the residual thyroid tissue and bilateral pathological lymph nodes detected on Tc99m-pertechnetate thyroid scintigraphy and positron emission tomography, the patient was re-operated but excision was incomplete. The patient's stage was T2N1aM0 (stage 3) according to the tumor node metastasis system proposed by the "American Joint Committee on Cancer" (13). Molecular testing revealed a heterozygous mutation in NF1 gene [IVS38-2A > G (c.5610-2A > G) both in our patient and his brother. There was no NF1-related mutation in his mother. In addition, homozygous RET proto-oncogene mutation [c.2671T > G (p.S891A) (p.Ser891Ala)] was found in the patient with a heterozygous mutation in his mother, father and brother (Figure 2). As a result of incomplete removal of lymph nodes and remaining thyroid tissue, serum calcitonin level was $1563 \mathrm{pg} / \mathrm{mL}$ and serum CEA level was $57.28 \mathrm{ng} / \mathrm{mL}$. Vandetanib treatment was initiated at a dose of $300 \mathrm{mg} /$ day. Serum calcitonin levels at the sixth, twelfth and twentyfourth months of treatment were $34.7 \mathrm{pg} / \mathrm{mL}, 4.4 \mathrm{pg} / \mathrm{mL}$ and $1.2 \mathrm{pg} / \mathrm{mL}$, while CEA levels were $12 \mathrm{ng} / \mathrm{mL}, 3.2 \mathrm{ng} /$

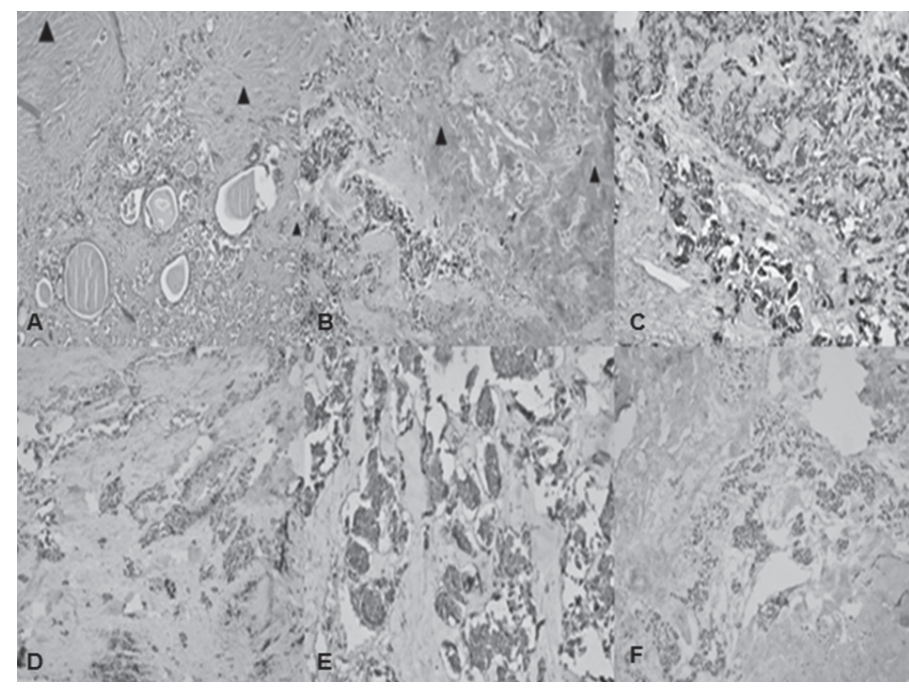

Figure 1. (A) Large areas of amyloid deposits (black triangle) can be seen around and between tumor cells and thyroid follicules (Hematoxylin and eosin x100), (B) Large deposits of amyloid (black triangle) in thyroid parenchyma (Congo Red x100), (C) Tumor cells showed positive immunoreactivity against monoclonal carcinoembryonic antigen (CEA) antibodies (CEA x200), (D) Tumor cells showed positive immunoreactivity against monoclonal calcitonin antibodies (Calcitonine x100), (E) Tumor cells showed positive immunoreactivity against monoclonal chromogranin antibodies (Chromogranin x200), (F) Tumor cells showed positive immunoreactivity against monoclonal TTF-1 antibodies (TTF-1 x100) 


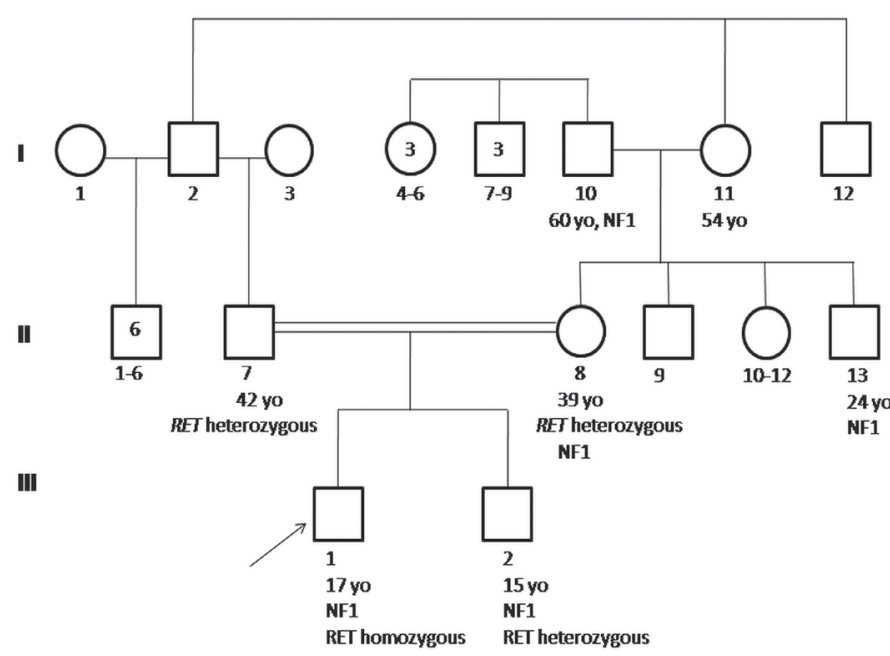

Figure 2. The pedigree of the family with NF1 and RET mutations; the arrow (III-1) indicates the proband

$\mathrm{mL}$ and $1.1 \mathrm{ng} / \mathrm{mL}$, respectively. The patient has been on vandetanib treatment for 32 months and no residual tissue and lymphadenopathy were detected in the neck tomography taken at the $30^{\text {th }}$ month of the treatment. No side effects were observed during vandetanib treatment in our patient in this period.

\section{Discussion}

Besides leukemia, somatic NF1 mutations have been reported in various cancers occurring in many different regions such as breast, colorectum, urothelium, lung, ovary, skin and nerve tissues (14). In addition, pheochromocytoma, parathyroid carcinoma, somatostatin producing neuroendocrine tumors, duodenal carcinoid tumors, and thyroid papillary carcinoma are reported endocrine neoplasms in patients with NF1. In these patients, it can be assumed that NF1 mutations predispose to the development of endocrine tumors by affecting the growth and differentiation of parafollicular $\mathrm{C}$ cells, parathyroid cells and other cells from which different endocrine tumors develop.

To our knowledge, MTC has not been reported in patients with NF1 mutation. In these patients, the cause of this association is unclear because no germ-line mutation in the RET gene could be demonstrated. Mutations in both the NF1 and RET genes have been described to date only in one case with thyroid $C$ cell hyperplasia (12). Our case is remarkable since it is the first case of MTC in which both NF1 gene and RET proto-oncogen mutation were identified simultaneously.

MTC is a rare tumor originating from the parafollicular or C-cells of the thyroid gland. MTC is sporadic in $75 \%$ of patients and usually occurs in the fourth to sixth decade of life. Less commonly, hereditary MTCs are found in MEN2A or MEN2B or as a part of familial MTC (15). RET protooncogene mutation is detected in almost all hereditary cases and in more than $40 \%$ of sporadic cases (15).

In our patient, homozygous mutation was detected in codon 891 in the RET gene. The p.S891A mutation was first described by Hofstra et al (16) in 1997 and associated with MEN 2A and MTC. Less than $5 \%$ of all MTC patients reported to date have RET mutationorrected as P.S891 A and this mutation is reported to be heterozygous because RET oncogene, acts dominantly as is usual in oncogenes (17). Giacché et al (18) analyzed 251 relatives of individuals with 28 p.S891 A mutations and reported that 108 had asymptomatic carriage and 64 had undergone thyroidectomy. As a result of histological examination, they reported that the mean age of patients with C-cell hyperplasia, micro-MTC and MTC was $30.2 \pm 13.7,37.9 \pm 10.3$ and $55.0 \pm 14.7$, respectively, and that malignancy development increased with age in individuals carrying the p.S891 A mutation. As a result of the ItaMEN study, in which the germline RET mutations of 250 families with hereditary MTC were evaluated, the p.S891 A mutation was present in $9.2 \%$ and was lower than other European studies (19). Also Schulte et al (20) stated that they found p.S891A mutation in $5 \%$ of patients followed up for MEN 2A. According to our knowledge there is only one study about the frequency of p.S891 A mutation in Turkish patients (21). In this study 12 different RET oncogen mutations were detected in 32 of 155 patients who were diagnosed with isolated MTC or as part of MEN2, and p.S891A mutation was reported in two patients $(6 \%)$. In this case the mutation was homozygous and, to our knowledge, it was not reported previously. The p.S891A mutation poses a moderate risk for MTC development according to the American Thyroid Association (ATA). The recommended ATA approach in individuals with moderate-risk RET mutations is to follow annual calcitonin and perform a total thyroidectomy when high values are detected (22). The mothers, fathers and siblings of our patient with heterozygous p.S891 A mutations did not have any symptoms, pathological examination or laboratory findings in favor of cancer. Since the mother and father carry a moderately risky mutation according to ATA criteria and MTC risk will increase in later years, prophylactic thyroidectomy was recommended but they did not accept. Similarly, the family preferred long-term followup instead of total thyroidectomy for the other child with a heterozygous p.S891 A mutation.

The NF1 gene encodes neurofibromin, a GTPase-activating protein that negatively regulates the Ras/mitogen-activated protein kinase (MAPK) signalling pathway (23). Loss-of- 
function mutations in NF1 lead to uncontrollable activation of kinase and tumorigenesis. Also, the RET protooncogene encodes a receptor tyrosine kinase that mediates extracellular neurotropic signaling to intracellular transduction pathways including the MAPK/ERK pathway (24). We think that these two diseases occurred coincidentally, because MTC in our patient does not have a common etiological pathway with the NF1, according to the evidence concerning both the NF1 gene and the RET oncogene.

Our patient was investigated for MEN2 due to RET proto oncogene mutation and MTC. In the family history, we learned that there were no patients with thyroid disease and therefore operated. RET proto-oncogene mutation analysis of the parents revealed that they were carriers of germ-line S891A mutation. On three-generation pedigree analysis no family member with cancer, including MTC, was reported. Although we could not perform the molecular testing of the RET gene for the rest of the family, since they lived in different cities, we believe the maternal grandmother and paternal grandfather to be carriers because they were siblings and the case had a homozygous mutation. The case was thought to be familial MTC although there was no clinical or laboratory finding in any of the heterozygotes, despite the mutation in the family; and currently follow-up was performed without prophylactic thyroidectomy.

In the follow-up of our patient, it was thought that vandetanib treatment would be appropriate, since residual tissue was still present after the second operation. Vandetanib is an orally available tyrosine kinase inhibitor that targets vascular endothelial growth factor dependent tumor angiogenesis and epidermal growth factor receptor, RET and RET dependent tumor cell proliferation (25). Several studies have evaluated the efficacy of vandetanib in the treatment of advanced MTC. In the ZETA trial, 331 patients with $5 \%$ local advanced stage and $95 \%$ metastatic MTC were randomized to vandetanib and placebo. At the end of the study, it was determined that the median survival of 19.3 months in the placebo group and the median 30.5 months in the vandetanib group were progression-free survival and a significant difference was found between the two groups (26). In a meta-analysis, $300 \mathrm{mg}$ of vandetanib treatment was demonstrated to have a better objective response than $150 \mathrm{mg}$ of vandetanib treatment (27). When compared to $150 \mathrm{mg}$ and $300 \mathrm{mg}$ vandetanib treatments, Hu et al (28) showed that administration of $300 \mathrm{mg}$ increased overall response rate.

The efficacy of vandetanib in childhood and adolescence was investigated in 16 patients aged 5-18 years with locally advanced or metastatic MEN2B-associated MTC. In this study, the dose of vandetanib was $100 \mathrm{mg} / \mathrm{m}^{2}$. M918T RET germline mutation was present in 15 patients and 7 of them (47\%) had a partial response (29). Kraft et al (30) reported that the duration of vandetanib therapy was 6.1 (0.1-9.7+) years in children treated with vandetanib, which lasted a median of 7.4 years and that progression-free survival was 6.7 years. Our patient has been receiving vandetanib for two years and serum calcitonin and CEA levels gradually decreased and reached the normal reference range. Since the dose we administer is higher than the dose in other pediatric studies and our patient is 15 years old, we think that the $300 \mathrm{mg} /$ day dose stated in adult studies may have contributed to our good response. Also, considering that vandetanib suppresses RET oncogene and RET oncogene dependent cell proliferation, we hypothesize that the high dose we applied may be more effective due to the homozygous mutation in our patient.

\section{Conclusion}

In conclusion, it should be kept in mind that different endocrinological tumors may rarely develop with NF1 and the patients should be carefully evaluated in this regard. Furthermore, we believe that vandetanib dose for children, especially for older or adolescent children, with MTC may be the same as in adults but this needs to be supported by further pediatric studies with larger sample size.

\section{Ethics}

Informed Consent: Written informed consent was obtained from the patient's parents for publication of this case report and the accompanying images.

Peer-review: Externally peer-reviewed.

\section{Authorship Contributions}

Surgical and Medical Practices- Concept - Design - Data Collection or Processing - Analysis or Interpretation Literature Search - Writing: Begümhan Demir Gündoğan, Fatih Sağcan, Sevcan Tuğ Bozdoğan, Yüksel Balcı, Ferah Tuncel Daloğlu, Elvan Çağlar Çıtak.

Financial Disclosure: The authors declared that this study received no financial support.

\section{References}

1. Bizzarri C, Bottaro G. Endocrine implications of neurofibromatosis 1 in childhood. Horm Res Paediatr 2015;83:232-241. Epub 2015 Feb 5

2. Wong CL, Fok CK, Tam VH. Concurrent primary hyperparathyroidism and pheochromocytoma in a Chinese lady with neurofibromatosis type 1. Endocrinol Diabetes Metab Case Rep 2018:28;2018.

3. Kim BK, Choi YS, Gwoo S, Park YH, yang SI, Kim JH. Neurofibromatosis type 1 associated with papillary thyroid carcinoma incidentally detected by thyroid ultrasonography: a case report. J Med Case Rep 2012;6:179 
4. Taccaliti A, Silvetti F, Palmonella G, Boscaro M. Genetic alterations in medullary thyroid cancer: diagnostic and prognostic markers. Curr Genomics 2011;12:618-625.

5. Hansen OP, Hansen M, Hansen HH, Rose B. Multiple endocrine adenomatosis of mixed type. Acta Med Scand 1976;200:327-331.

6. Yoshida A, Hatanaka S, Ohi Y, Umekita Y, Yoshida H. Von Recklinghausen's disease associated with somatostatin-rich duodenal arcinoid (somatostatinoma), medullary thyroid carcinoma and diffuse adrenal medullary hyperplasia. Acta Pathol Jpn 1991;41:847-856.

7. Barbot N, Calmettes C, Schuffenecker I, Saint-André JP, Franc B, Rohmer $\mathrm{V}$, Jallet P, Bigorgne JC. Pentagastrin stimulation test and early diagnosis of medullary thyroid carcinoma using an immunoradiometric assay of calcitonin. Comparison with genetic screening in hereditary medullary thyroid carcinoma. J Clin Endocrinol Metab 1994;78:114-120.

8. Pages A, Marthy C, Baldet P, Péraldi R. Neurofibromatosis-thyroid medullary carcinoma-pheochromocytoma syndrome. Arch Anat Pathol 1970;18:137-142. (French)

9. Schimke RN. Multiple endocrine neoplasia: how many syndromes? Am J Med Genet 1990;37:375-383.

10. Segni Massa R, Bonifacio V, Bonifacio V, Tartaglia F, Pucarelli I, Marzullo A, Pasquino AM. Thyroid C-cell hyperplasia in an adolescent with neurofibromatosis type 1. Horm Res 2001;56:63-66.

11. Gieldon L, Masjkur JR, Richter S, Därr R, Lahera M, Aust D, Zeugner S, Rump A, Hackmann K, Tzschach A, Januszewicz A, Prejbisz A, Eisenhofer G, Schrock E,Robledo M, Klink B. Next-generation panel sequencing identifies NF1 germline mutations in three patients with pheochromocytoma but no clinical diagnosis of neurofibromatosis type 1. Eur J Endocrinol 2018;178:K1-9. Epub 2017 Nov 20

12. Ercolino T, Lai R, Giachè V, Melchionda S, Carella M, Delitala A, Mannelli M, Fanciulli G. Patient affected by neurofibromatosis type 1 and thyroid C-cell hyperplasia harboring pathogenic germ-line mutations in both NF1 and RET genes. Gene 2014;536:332-335. Epub 2013 Dec 21

13. Edge SB, Byrd DR, Compton CC, Gershenwald JE, Brookland RK, Meyer L, Gress DM, Meyer LR. AJCC Cancer Staging Manual. 7th ed. New York:Springer. 2010.

14. Mahalingam M. NF1 and Neurofibromin: Emerging Players in the Genetic Landscape of Desmoplastic Melanoma. Adv Anat Pathol 2017;24:1-14.

15. Fagin JA, Wells Jr. SA. Biologic and clinical perspectives on thyroid cancer. N Eng1 J Med 2016;15:1054-1067.

16. Hofstra RM, Fattoruso O, Quadro L, Wu Y, Libroia A, Verga U, Colantuoni $\mathrm{V}$, Buys $\mathrm{CH}$. A novel point mutation in the intracellular domain of the ret protooncogene in a family with medullary thyroid carcinoma. J Clin Endocrinol Metab 1997;82:4176-4178

17. Santoro M, Carlomagno F, Romano A, Bottaro DP, Dathan NA, Grieco M, Fusco A, Vecchio G, Matoskova B, Kraus MH, Di Fiore PP. Activation of RET as a dominant transforming gene by germline mutations of MEN2A and MEN2B. Science 1995;267:381-383.

18. Giacché M, Panarotto A, Tacchetti MC, Tosini R, Campana F, Mori L, Cappelli C,Pirola I, Lombardi D, Pezzola DC, Casella C, Castellano M. p.Ser891Ala RET gene mutations in medullary thyroid cancer: Phenotypical and genealogical characterization of 28 apparently unrelated kindreds and founder effect uncovering in Northern Italy. Hum Mutat 2019;40:926-937. Epub 2019 Apr 29

19. Romei C, Mariotti S, Fugazzola L, Taccaliti A, Pacini F, Opocher G, Mian C, Castellano M, degli Uberti E, Ceccherini I, Cremonini N, Seregni E, Orlandi F, Ferolla P, Puxeddu E, Giorgino F, Colao A, Loli P, Bondi F,
Cosci B, Bottici V, Cappai A, Pinna G, Persani L, Verga U, Boscaro M, Castagna MG, Cappelli C, Zatelli MC, Faggiano A, Francia G, Brandi ML, Falchetti A, Pinchera A, Elisei R; ItaMEN network. Multiple endocrine neoplasia type 2 syndromes (MEN 2): results from the ItaMEN network analysis on the prevalence of different genotypes and phenotypes. Eur J Endocrinol 2010;163:301-308. Epub 2010 Jun 1

20. Schulte KM, Machens A, Fugazzola L, McGregor A, Diaz-Cano S, Izatt L, Aylwin S, Talat N, Beck-Peccoz P, Dralle H. The clinical spectrum of multiple endocrine neoplasia type $2 \mathrm{a}$ caused by the rare intracellular RET mutation S891 A. J Clin Endocrinol Metab 2010;95:E92-E97. Epub 2010 Jun 16

21. Tekin IM, Onay H, Aykut A, Karaca E, Atik T, Turan C, Özger G, Erdogan M, Ozkinay F. RET mutation spectrum in Turkish cases with medullary thyroid carcinoma: definition of a novel K710R mutation. J Clin Res Pediatr Endocrinol 2015;7(Suppl 2):77-92.

22. Türkiye Endokrin ve Metabolizma Derneği Tiroid Hastalıkları Tanı ve Tedavi Klavuzu 2019. Last Accessed date: 04.08.2021. Available from: http://temd.org.tr/admin/uploads/tbl_kilavuz/201904261653402019tbl_kilavuze72e4ddf38.pdf

23. Laycock-van Spyk SL, Thomas N, Cooper DN, Upadhyaya M. Neurofibromatosis type 1-associated tumours: Their somatic mutational spectrum and pathogenesis. Hum Genomics 2011;5:623690.

24. Cortés JMR, Zerón HM. Genetics of Thyroid Disorders. Folia Med (Plovdiv) 2019;61:172-179

25. Herbst RS, Heymach JV, O'Reilly MS, Onn A, Ryan AJ. Vandetanib (ZD6474), an orally available receptor tyrosine kinase inhibitor that selectively targets pathways critical for tumor growth and angiogenesis. Expert Opin Investig Drugs 2007;16:239-249.

26. Wells SA Jr, Robinson BG, Gagel RF, Dralle H, Fagin JA, Santoro M, Baudin E, Elisei R, Jarzab B, Vasselli JR, Read J, Langmuir P, Ryan AJ, Schlumberger MJ. Vandetanib in patients with locally advanced or metastatic medullary thyroid cancer: a randomized, double-blind phase III trial. J Clin Oncol 2012;30:134-141. Epub 2011 Oct 24

27. Tsoli M, Alexandraki KI, Spei ME, Kaltsas GA, Daskalakis K. Antitumor activity and safety of multikinase inhibitors in advanced and/ or metastatic thyroid cancer: A systematic review and network metaanalysis of randomized controlled trials. Horm Metab Res 2020;52:2531. Epub 2019 Oct 30

28. Hu MI, Elisei R, Dedecjus M, Popovtzer A, Druce M, Kapiteijn E, Pacini F, Locati L, Krajewska J, Weiss R, Gagel RF. Safety and efficacy of two starting doses of vandetanib in advanced medullary thyroid cancer. Endocr Relat Cancer. 2019;26:241-250.

29. Fox E, Widemann BC, Chuk MK, Marcus L, Aikin A, Whitcomb PO, Merino MJ, Lodish M, Dombi E, Steinberg SM, Welss SA, Balis FM. Vandetanib in children and adolescents with multiple endocrine neoplasia type 2B associated medullary thyroid carcinoma. Clin Cancer Res 2013;19:4239-4248. Epub 2013 Jun 13

30. Kraft IL, Akshintala S, Zhu Y, Lei H, Derse-Anthony C, Dombi E, Steinberg SM, Lodish M, Waguespack SG, Kapustina O, Fox E, Balis FM, Merino MJ, Meltzer PS, Glod JW, Sherm JF, Widemann BC. Outcomes of children and adolescents with advanced hereditary medullary thyroid carcinoma treated with vandetanib. Clin Cancer Res 2017;24:753-765. Epub 2017 Nov 29 